\title{
Pengaruh penggunaan larutan kulit pisang goroho (Musa acuminate $L$ ) terhadap sifat fisik telur ayam ras
}

\author{
D.F. Datukramat, R. Hadju*, A. Yelnetty, M. Tamasoleng. \\ Fakultas Peternakan Universitas Sam Ratulangi Manado 95115 \\ *Korespondensi (corresponding author): rhadju19@gmail.com
}

\begin{abstract}
ABSTRAK
Penelitian ini bertujuan untuk mengetahui pengaruh penggunaan larutan kulit pisang goroho terhadap sifat fisik telur ayam ras selama penyimpanan. Bahan yang digunakan dalam penelitian ini adalah telur ayam ras yang masih segar sebanyak 40 butir dengan berat $65-70 \mathrm{~g}$ dan kulit buah pisang goroho. Kulit pisang goroho diperoleh dari penjual pisang goreng yang berada ditepi pantai Malalayang, Manado. Alat-alat yang digunakan dalam penelitian adalah pisau, timbangan, wadah, diameter caliper, tisu, kaca, kompor, panci, kain belacu, karet gelang, kantong plastik, kertas sampel, dan gelas ukur 1000ml. Metode yang digunakan pada penelitian ini adalah metode rancangan acak lengkap (RAL) yang terdiri dari 4 perlakuan dan 5 ulangan dan variabel yang diamati yaitu perubahan berat telur, indeks putih telur dan indeks kuning telur. Data yang diperoleh dianalisis menggunakan anova. Hasil penelitian menunjukkan bahwa terdapat perbedaan yang nyata $(\mathrm{P}<0,05)$ terhadap perubahan berat telur, indeks putih telur dan indeks kuning telur. Perendaman telur dalam konsentrasi sampai $40 \%$ larutan kulit pisang goroho dengan penyimpanan selama 30 hari, berpengaruh secara nyata terhadap perubahan berat telur, indeks putih telur dan indeks kuning telur.
\end{abstract}

Kata Kunci: Telur Ayam Ras, Kulit Pisang Goroho, Sifat Fisik.

\begin{abstract}
EFFECT OF USE OF GOROHO BANANA (Musa acuminate L) PEEL SOLUTION ON THE PHYSICAL CHARACTERISTICS OF PUREBRED CHICKEN EGGS. This study aims to evaluate the effect of the use of goroho banana peel solution on the physical characteristics of purebred chicken eggs during storage. The ingredients used in this study were 40 eggs of fresh purebred laying hens weighing of 65-70g and goroho banana peels. The goroho banana peels were obtained from fried banana sellers located on the shore of Manado Malalayang beach. The tools used in this study were areknife, scales, container, diameter caliper, tissue, glass, stove, pan, cloth belacu, rubber band, plastic bag, sample paper, and measuring glass $1000 \mathrm{ml}$ capacity. The method used in this study was a completely randomized design method consist of 4 treatments and 5 replication at each treatment. The observed variables were changes in egg weight, egg whites and egg yolk index. The data obtained were analyzed using anova. The results showed that there was a noticeable difference $(\mathrm{P}<0.05)$ to changes in egg weight, egg white index and egg yolk index. Immersion of eggs in concentrations up to $40 \%$ solution of goroho banana peels with storage for 30 days had a noticeable effect on changes in egg weight, egg white index and egg yolk index.
\end{abstract}

Keywords: Purebred chicken eggs, goroho banana peels, physical characteristics. 


\section{PENDAHULUAN}

Telur merupakan sumber protein hewani mudah didapat, mengandung asam amino esensial, sehingga sering dijadikan patokan dalam menentukan mutu protein berbagai bahan pangan (Tindjabate et al., 2014). Disisi lain telur mudah mengalami penurunan kualitas yang disebabkan oleh kerusakan secara fisik, serta penguapan air, karbondioksida, ammonia, nitrogen, dan hidrogen sulfida dari dalam telur (Muchtadi et al., 2010).

Kerusakan telur dapat disebabkan oleh adanya kontaminasi mikroba dari luar yang masuk melalui pori-pori kerabang telur dan kemudian merusak isi telur. Penguapan air dan gas juga dapat merusak isi telur. Akibat penguapan yang terjadi didalam telur membuat bobot telur menyusut, dan putih telur menjadi lebih encer (Lupitasari et al., 2017; Sigar et al., 2020). Hal-hal ini yang membuat telur merupakan produk pangan yang mudah rusak dalam waktu singkat sehingga perlu dilakukan penanganan untuk memperpanjang masa simpan.

Prinsip penyimpanan telur adalah memperkecil penguapan $\mathrm{CO}_{2}$ dan $\mathrm{H}_{2} \mathrm{O}$ dari dalam telur (Wedana et al., 2017). Itulah sebabnya perlu perlu dilakukan suatu teknologi pengawetan. Teknologi pengawetan telur dibutuhkan untuk menutup pori-pori kerabang telur agar telur tidak terjadi penguapan yang lama. Terdapat beberapa penelitian yang telah menerapkan teknologi pengawetan dengan menggunakan bahan-bahan alami seperti biji alpukat (Sigar et al., 2020), Aloe vera (Lamarang et al., 2019); ekstrak daun melinjo (Lestari et al., 2018); daun jambu biji (Azizah et al., 2018). Penggunaan bahan-bahan alami untuk pengawetan, Sebagian besar disebabkan karena kandungan tannin yang terkandung dalam bahan tersebut. Diantara berbagai bahan yang telah digunakan untuk pengawetan telur, terdapat bahan alami yang belum disentuh oleh peneliti yakni kulit buah pisang goroho (Musa acuminate $\mathrm{L}$ ).
Kulit pisang goroho (Musa acuminate L) merupakan limbah dari buah pisang yang belum termanfaatkan.Buah pisang yang belum matang banyak mengandung tanin terutama pada kulit buah. Kulit pisang goroho juga mengandung kadar tannin sebesar 6,84\% pada kulit pisang mentah, $4,97 \%$ pada kulit pisang goroho hamper matang, dan 4,69\% pada kulit pisang goroho matang (Alhabsyi et al., 2014). Mirnawati (2018) pernah meneliti mengenai kulit pisang kulit pisang (Musa paradisiaca L) untuk pengawetan telur, namun penelitiannya menggunakan pisang dari spesies yang lain tentunya mempunyai kandungan tannin yang berbeda dengan Musa acuminate $\mathrm{L}$.

Berdasarkan penjelasan dan uraian diatas, maka dilakukan penelitian dengan tujuan menggunakan kulit pisang goroho (Musa acuminate $\mathrm{L}$ ) sebagai pengawet pada telur ayam ras.

\section{MATERI DAN METODE PENELITIAN}

Penelitian ini telah dilakukan pada tanggal 31 agustus 2020 - tanggal 30 september 2020, di Lab Teknologi Hasil Ternak Fakultas Peternakan, Universitas Sam Ratulangi Manado.Peralatan yang digunakan dalam penelitian ini adalah timbangan analitik, diameter caliper, dan gelas ukur $1000 \mathrm{ml}$. Bahan yang digunakan dalam penelitian ini adalah telur ayam ras segar sebanyak 40 butir dengan berat 65 $70 \mathrm{~g}$ dan kulit buah pisang goroho.

\section{Metode penelitian}

Penelitian ini dilaksanakan melalui suatu percobaan dengan menggunakan rancangan acak lengkap (RAL) yang terdiri dari 4 perlakuan dan 5 ulangan. Perlakuan tersebut terdiri dari (Steel dan Torrie, 1993):

P0: Kontrol, tanpa rendaman larutan kulit pisang goroho

P1: Direndam dalam larutan kulit pisang goroho $20 \%$ 
P2: Direndam dalam larutan kulit pisang goroho $30 \%$

P3: Direndam dalam larutan kulit pisang goroho $40 \%$

\section{Pembuatan larutan kulit pisang goroho}

1. Persiapan bahan yaitu telur ayam ras segar dari peternakan Bapak Gunawan dan kulit buah pisang yang diperoleh dari penjual pisang goreng dipinggir pantai Malalayang, Manado.

2. Pembuatan larutan kulit pisang dengan cara kulit buah pisang yang belum matang yang telah dipisahkan dari daging buahnya diiris tipis-tipis kemudian dijemur dibawah sinar matahari sampai kering (tiga hari). Selanjutnya kulit buah pisang yang sudah kering direbus selama 15 menit (konsentrasi $20 \%$ yaitu $1.000 \mathrm{ml}$ dengan 200 gr masing-masing kulit buah pisang, konsentrasi $30 \%$ yaitu $1.000 \mathrm{ml}$ dengan 300 gr kulit buah pisang, dan konsentrasi $40 \%$ yaitu $1.000 \mathrm{ml}$ dengan 400 gr kulit buah pisang). Hasil rebusan didinginkan, kemudian diperas dan disaring untuk diambil larutannya. Selanjutnya larutan tersebut digunakan untuk merendam telur selama 24 jam.

\section{Prosedur penelitian}

1. Persiapan telur yang sudah dibersihkan dari kotoran yang menempel pada kulit telur sebanyak 40 butir dengan berat 65 70 gram dan telah diamplas.

2. Persiapan wadah/tempat perendaman telur yang telah berisi larutan kulit pisang sebanyak 8 buah yang diberi label sesuai perlakuan, dimana pada masingmasing terdapat 5 butir telur.

3. Setelah itu telur direndam dalam larutan kulit pisang sampai telur terbenam seluruhnya.

4. Setelah perendaman selama 24 jam pada masing-masing perlakuan, telur diangkat dari rendaman kemudian disimpan pada suhu ruangan selama 30 hari.

\section{Variabel yang diteliti}

Setelah proses perendaman, pada akhir penelitian dilakukan penimbangan perubahan berat telur dan mengamati indeks putih telur dan indeks kuning telur, adapun yang diamati yaitu:

1. Perubahan berat telur

Perubahan berat telur dihitung dengan cara menimbang berat awal telur (gram), dikurangi dengan berat akhir telur (gram) setelah disimpan, dibagi dengan berat awal telur (gram), dan kemudian dikali 100\%, (Muchtadi et al., 2009), dihitung dengan rumus:

$$
\frac{\text { BeratAwal }(\text { gram })-\text { BeratAkhir }(\text { gram })}{\text { BeratAwal }(\text { gram })} \times 100 \%
$$

2. Metode pengujian indeks putih telur Indeks putih telur adalah rasio tinggi putih telur kental terhadap rata-rata diameter terpanjang dan terpendek dari putih telur. Telur dipecahkan dan diletakkan diatas kaca. Kemudian tinggi dan diameter putih telur diukur (Wulandari et al., 2013), dan dihitung menggunakan rumus:

$$
\text { IndeksPutihTelur }=\frac{\text { TinggiPutihTelur }}{\text { DiameterPutihTelur }} \times 100 \%
$$

3. Metode pengujian indeks kuning telur Indeks kuning telur merupakan perbandingan antara tinggi dan diameter kuning telur sama seperti mengukur indeks putih telur (Wulandari et al., 2013). Pengukuran pengukuran diameter kuning telur menurut Andi (2013) diukur dengan menggunakan jangka sorong, selanjutnya dilakukan pengukuran tinggi kuning telur dengan cara menancapkan lidi pada kuning telur, kemudian lidi tersebut diukur dengan menggunakan penggaris. Rumus indeks kuning telur dihitung menggunakan rumus:

$$
\text { IndeksKuningTelur }=\frac{\text { TinggiKuningTelur }}{\text { DiameterKuningTelur }} X 100 \%
$$

\section{Analisa data}

Data yang diperoleh pada penelitian ini diolah dengan menggunakan analisis ragam berdasarkan rancangan acak lengkap (RAL) pola faktorial 4 x 5 dengan 5 kali ulangan (Steel dan Torrie, 1993), dan 
jika ada yang berpengaruh nyata akan dilanjutkan dengan uji beda nyata jujur (BNJ) (Steel dan Torrie, 1993).

\section{HASIL DAN PEMBAHASAN}

Hasil penelitian selama 30 hari yang mencakup, perubahan berat telur, indeks putih telur, dan indeks kuning telur pada telur ayam ras.

\section{Perubahan berat telur}

Hasil penelitian pengawetan telur dengan metode perendaman larutan kulit pisang goroho pada telur ayam ras dan penyimpanan selama 30 hari. Nilai perubahan berat telur dapat dilihat pada Tabel 1.

Berdasarkan Tabel 1, rataan perubahan berat telur selama penyimpanan 30 hari bertururt-turut dengan perendaman larutan kulit pisang goroho, memiliki nilai terendah pada perlakuan perendaman telur dengan larutan kulit pisang goroho sebanyak $40 \%(0,02 \mathrm{~g})$, diikuti perlakuan sebanyak 30\% (0,04 g), 20\% (0,04 g), dan tanpa perlakuan $0 \%(0,05 \mathrm{~g})$.

Hasil analisis ragam menunjukkan pengaruh yang nyata $(\mathrm{P}<0,05)$ terhadap nilai perubahan berat telur. Hasil ini berbeda dengan penelitian sebelumnya oleh Mirnawati (2018), perendaman larutan kulit pisang kepok terhadap perubahanberat telur yang memberikan hasil tidak berbeda nyata.

Berdasarkan hasil uji BNJ menunjukkan bahwa perubahan berat telur ayam ras yang direndam dalam larutan kulit pisang goroho pada perlakuan P3 berpengaruh sangat nyata $(\mathrm{P}<0,5)$ dengan P1 dan P2. Kemudian P1 dan P2 tidak berpengaruh nyata $(\mathrm{P}>0,05)$, Selanjutnya $\mathrm{P} 0$ berpengaruh sangat nyata $(\mathrm{P}<0,5)$. Hasil uji BNJ perubahan berat telur menunjukkan bahwa perlakuan P3 dan P0 lebih baik dibandingkan dengan perlakuan P1 dan P2. Perlakuan P3 (0,02 g) dengan larutan kulit pisang goroho $40 \%$ dapat menunjukkan perubahan berat telur yang kecil yang berarti makin banyak tanin yang terikat maka semakin kecil perubahan berat telur yang didapat. Hal ini menunjukkan bahwa semakin tinggi nilai konsentrasi larutan kulit pisang goroho yang digunakan untuk merendam telur maka nilai perubahan berat telur semakin rendah. Hal ini disebabkan oleh kandungan tanin pada perlakuan $40 \%$ terikat pada protein selama penyimpanan sehingga mampu melapisi dan menutupi pori-pori kerabang telur untuk menghambat transfer air dan karbondioksida. Didukung Herly (2018), menyatakan bahwa tanin merupakan salah satu jenis polifenol yang secara alami terdapat dalam beberapa tanaman dan mempunyai kemampuan untuk mengikat protein didalam telur. Sehingga kandungan tanin yang terdapat didalam kulit pisang goroho terserap kedalam telur selama perendaman.

Menurut Siregar et al. (2012) bahwa menurunnya berat telur disebabkan karena terjadinya pelepasan gas seperti $\mathrm{CO}_{2}, \mathrm{NH}_{2}$, $\mathrm{N}_{2}$, dan $\mathrm{H}_{2} \mathrm{~S}$ dan penguapan air serta pelepasan gas tersebut terjadi terus menerus maka berat telur lama kelamaan turun. Perubahan berat telur yang disimpan 1-15 hari pada telur ayam ras berkisar antara 0,93,02 (Sihombing, 2013).

Riawan et al. (2017) menyatakan bahwa telur dapat mengalami kerusakan fisik yang disebabkan oleh bakteri. Dijelaskan lebih lanjut bahwa meningkatnya lama penyimpanan sejalan dengan meningkatnya bakteri dalam telur. Faktor lain yang mempengaruhi kerusakan (penurunan berat telur) yaitu suhu, kelembaban ruang penyimpanan, kotoran pada kulit telur dan teknik penanganan serta peralatan yang digunakan dalam penanganan.

\section{Indeks putih telur}

Berdasarkan Tabel 1, rataan indeks putih telur menggunakan perlakuan perendaman larutan pisang goroho berkisar antara $0,01 \mathrm{~mm}-0,04 \mathrm{~mm}$. Hasil penelitian ini lebih rendah dibandingkan yang dilaporkan oleh Ernawati et al. (2019), dimana indeks putih telur yang direndam menggunakan larutan daun 
Tabel 1. Pengaruh Perendaman Larutan Kulit Pisang Goroho Terhadap Perubahan Berat Telur, Indeks Putih Telur dan Indeks Kuning Telur.

\begin{tabular}{lcccc}
\hline \multirow{2}{*}{ Variabel } & P0 & P1 & P2 & P3 \\
\cline { 2 - 5 } & $0 \%$ & $20 \%$ & $30 \%$ & $40 \%$ \\
\hline PerubahanBerattelur (g) & $0,05^{\mathrm{c}}$ & $0,04^{\mathrm{b}}$ & $0,04^{\mathrm{b}}$ & $0,02^{\mathrm{a}}$ \\
IndeksPutihTelur (mm) & $0,01^{\mathrm{a}}$ & $0,01^{\mathrm{a}}$ & $0,02^{\mathrm{b}}$ & $0,04^{\mathrm{c}}$ \\
IndeksKuningTelur (mm) & $0,12^{\mathrm{a}}$ & $0,20^{\mathrm{b}}$ & $0,24^{\mathrm{bc}}$ & $0,37^{\mathrm{d}}$ \\
\hline
\end{tabular}

Ket: Superskip yang berbeda nyata pada baris yang sama menunjukan perbedaan yang nyata $(\mathrm{P}<0,05)$ dan (nonsignifikan) menunjukan tidak berbeda nyata $(\mathrm{P}>0,05)$.

jambu biji memberikan hasil $0,023 \mathrm{~mm}-$ $0,038 \mathrm{~mm}$.

Hasil analisis sidik ragam menununjukkan bahwa perlakuan interaksi konsentrasi larutan kulit pisang goroho $\mathrm{P0}$ $0 \%$, P1 20\%, P2 30\%, dan P3 40\% berepengaruh nyata $(\mathrm{P}<0,05)$ terhadap kualitas indeks putih telur. Berdasarkan hasil uji BNJ menunjukkan bahwa indeks putih telur yang direndam dalam larutan kulit pisang goroho pada perlakuanP2 dan P3 berbeda sangat nyata $(\mathrm{P}<0,05)$ dengan P1 dan P0. Kemudian P0 dan P1 tidak berbeda nyata $(\mathrm{P}>0,05)$.

Dapat disimpulkan data hasil uji BNJ perendaman telur menggunakan larutan kulit pisang goroho memberikan nilai indeks putih telur yang lebih baik dibandingkan dengan perlakuan P0 dan P1. Tampak bahwa bila dibandingkan dengan perlakuan P0 dan P1 maka perlakuan P3 $(0,04)$ memberikan indeks putih telur tertinggi daripada perlakuan P2 $(0,02)$. Fakta ini menunjukkan bahwa perlakuan perendaman telur menggunakan larutan kulit pisang goroho dengan konsentrasi 30 $\%$ dan $40 \%$ memberikan pengaruh terhadap peningkatan indeks putih telur. Hal ini disebabkan oleh bahan penyamak (tanin) yang terkandung didalam kulit pisang goroho mampu menutupi pori-pori kerabang telur sehingga gas $\mathrm{CO}_{2}$ dapat dihambat keluar dan menghambat mikroba masuk kedalamtelur dan kekentalan putih telur tetap terjaga.Hal ini sesuai dengan pendapat Azizah et al. (2017) yang menyatakan bahwa dengan pencegahan terjadinya penguapan air dan $\mathrm{CO}_{2}$ maka memperlambat kenaikan $\mathrm{pH}$ dan kekentalan putih telur dapat dipertahankan.

Tanin bereaksi dengan protein yang terdapat pada permukaan kerabang telur dan membentuk lapisan yang bersifat impermeable terhadap gas. Hal ini sesuai dengan pendapat Riawan (2017) yang menyatakan tanin dapat membunuh bakteri pada kerabang telur dengan cara merusak dinding sel bakteri dan mendenaturasi protein pada bakteri kerusakan pada dinding sel dapat menyebabkan kematian.

Hal ini berarti semakin besar konsentrasi larutan kulit pisang goroho semakin baik terhadap indeks putih telur. Menurut BSN, (2008) menyatakan bahwa telur yang baru mempunyai indeks putih telur antara 0,050-0,174.

Menurut Kurtini et al. (2014), putih telur sebagian besar mengandung unsur anorganik natrium dan kalium bikarbonat, saat terjadi penguapan CO2selama penyimpanan maka putih telur menjadi alkalis yang berakibat $\mathrm{pH}$ putih telur meningkat.

Semakin lama penyimpanan maka tinggi lapisan putih telur kental akan menurun dengan cepat dan akhirnya penurunan tersebut akan semakin akan semakin lambat. Waktu penyimpanan yang semakin lama menyebabkan pori semakin besar dan rusaknya lapisan mukosa. Air, gas, dan bakteri lebih mudah melewati kerabang tanpa ada yang menghalangi, sehingga penurunan kualitas dan kesegaran telur semakin cepat terjadi (Azizah et al., 2017). 


\section{Indeks kuning telur}

Berdasarkan Tabel 1, rataan indeks kuning telur yang menggunakan konsentrasi larutan kulit pisang goroho berkisar antara $0,12 \mathrm{~mm}-0,37 \mathrm{~mm}$. Hasil penelitian ini lebih tinggi dibandingkan yang dilaporkan oleh Ernawati et al. (2019), dimana indeks kuning telur yang direndam menggunakan larutan daun jambu biji memberikan hasil 0,148 $\mathrm{mm}-$ $0,233 \mathrm{~mm}$.

Hasil analisis ragam menunjukkan bahwa perlakuanlarutan kulit pisang goroho P0 larutan kulit pisang goroho 0\%, P1 larutan kulit pisang goroho 20\%, P2 larutan kulit pisang goroho $30 \%$ dan P3 larutan kulit pisang goroho $40 \%$ memberikanpengaruh nyata $(\mathrm{P}<0,05)$ terhadap indeks kuning telur. Berdasarkan hasil uji BNJ menunjukkan bahwa indeks kuning telur yang direndam dalam larutan kulit pisang goroho menunjukkan bahwa perlakuan P3dan P0 berpengaruh nyata $(\mathrm{P}<0,05)$ dengan $\mathrm{P} 2$ dan $\mathrm{P} 1$ tidak berpengaruh nyata $(\mathrm{P}>0,05)$. Hasil uji $\mathrm{BNJ}$ indeks kuning telur dengan larutan kulit pisang goroho menunjukkan bahwa perlakuan P3 memberikan hasil terbaik bila dibandingkan dengan $\mathrm{P} 0$, dengan perlakuan larutan kulit pisang goroho $40 \%$ menghasilkan indeks kuning telur 0,037 mm karena memiliki indeks kuning telur tertinggi dan dengan indeks kuning telur yang tinggi akan menyebabkan telur semakin awet. Standar indeks kuning telur segar berkisar antara 0,33-0,52 mm (BSN, 2008). Hal ini dikarenakan kandungan tanin dalam kulit pisang goroho dengan konsentrasi $40 \%$ mampu menutupi poripori kerabang telur sehingga dapat menghambat penguapan air dan gas $\mathrm{CO}_{2}$, $\mathrm{NH}_{3}, \mathrm{~N}_{2}$, dan $\mathrm{H}_{2} \mathrm{~S}$ dengan sempurna sehingga tidak menyebabkan terjadinya migrasi air dari putih ke kuning telur. Hal ini sesuai dengan pernyataan Lestari et al. (2013) bahwa penyimpanan telur menyebabkan terjadinya pemindahan air dari putih telur menuju kuning telur. Tekanan osmotik kuning telur lebih besar dari putih telur sehingga air dari putih telur berpindah menuju kuning telur. Kuning telur akan menjadi semakin lembek sehingga indeks kuning telur menurun, kemudian membrane vitelin akan rusak dan menyebabkan perubahan kuning telur dari bulat menjadi masa yang kendur. Selanjutnya dalam penelitian Sigar et al. (2020) menyatakan bahwa tannin yang terdapat pada biji alpukat dapat mempertahankan kualitas indeks kuning telur selama penyimpanan 21 hari.

Standar indeks kuning telur segar berkisar antara 0,33-0,52 mm (BSN, 2008). Kandungan tanin dalam larutan kulit pisang goroho dapat menghambat laju proses transfer air dari putih ke kuning telur.

\section{KESIMPULAN}

Perendaman telur dalam konsentrasi sampai $40 \%$ larutan kulit pisang goroho dengan penyimpanan selama 30 hari, berpengaruh secara nyata terhadap perubahan berat telur, indeks putih telur dan indeks kuning telur.

\section{DAFTAR PUSTAKA}

Alhabsyi, D.F., E. Suryanto dan D.S. Wewengkang. 2014. Aktivitas antioksidan dan tabir surya pada ekstrak kulit buah pisang goroho (musa acuminate. L). Jurnal Ilmiah Farmasi 3(2): 107-114.

Andi, N.M. 2013. Pengaruh Level Ekstrak Daun Melinjo (Gnetum gnemon Linn) dan Lama Penyimpanan yang Berbeda Terhadap Kualitas Telur. Skripsi. Universitas Hasanuddin. Makasar.

Azizah, N., M. A. Djaelani dan S. M. Mardiati. 2017. Kandungan protein, indeks putih telur (ipt) dan haugh unit (hu) telur itik setelah perendaman dengan larutan daun jambu biji (psidium guajava) yang disimpan pada suhu $27^{\circ} \mathrm{C}$. Buletin Anatomi dan Fisiologi 3(1): 46-55.

Badan Standarisasi Nasional (BSN). 2008. SNI ISO 9001-2000 Sistem 
Manajemen Mutu Persyaratan Jakarta.

Ernawati, T., L.C.M. Karisoh, R. Hadju dan S.E. Siswosubroto. 2019. Pengaruh konsentrasi larutan daun jambu biji (psidium guajava) dan lama perendaman terhadap kualitas telur ayam ras. Zootec 39(2): 241-248.

Herly, M. 2018. Pemanfaatan Daun Jambu Biji Dan Daun Jati Beserta Kombinasinya Pada Lama Penyimpanan Yang Berbeda Terhadap Kualitas Organoleptik Telur Pindang. Skripsi. Fakultas Peternakan. Universitas Hasanudin Makasar.

Kurtini, T., K. Nova dan D. Septinova. 2014. Produksi Ternak Unggas Edisi Revisi. Aura Printing dan Publishing. Bandar Lampung.

Lamarang, A., A. Yelnetty, L.C.M. Karisoh dan N.N. Lontaan. 2020. Pengaruh lama perendaman dalam gel lidah buaya (aloe vera) terhadap kualitas telur ayam ras. Zootec 40(1): 150159.

Lestari, L., S.M. Mardiati dan M.A. Djaelani. 2018. Kadar protein, indeks putih telur, dan nilai hauhg unit telur itik setelah perendaman ekstrak daun salam dengan waktu penyimpanan yang berbeda pada suhu $4^{\circ} \mathrm{c}$. Jurnal Buletin Anatomi dan Fisiologi 3(1): 39-45.

Lupitasari, C., R. Somanjaya dan O. Imanudin. 2017. Uji tingkat kesukaan telur ayam ras hasil perendaman menggunakan ekstrak daun melinjo. Jurnal Ilmu-Ilmu Pertanian dan Peternakan 5(1): 104-113.

Mirnawati. 2018. Pemanfaatan Ekstrak Kulit Pisang (Musa paradisiaca L) Sebagai Bahan Pengawet Telur Ayam Ras. Skripsi. Universitas Islam Negeri Alauddin, Makassar.

Muchtadi, T.R., F. Ayustaningwarno dan Sugiyono. 2010. Ilmu Pengetahuan Bahan Pangan. Penerbit Alfabeta. Bandung
Riawan, R., R. Riyanti dan K. Nova. 2017. Pengaruh perendaman telur menggunakan larutan daun kelor terhadap kualitas internal telur ayam ras. Jurnal Ilmiah Peternakan 5(1): 17.

Sigar, A.C., E.H.B. Sondakh, F.S. Ratulangi dan C.K.M. Palar. 2020. Pengaruh perendaman dalam larutan ekstrak tanin biji alpukat terhadap kualitas internal telur ayam ras. Zootec 40(2): 794-803.

Sihombing. 2013. Formula Kebutuhan Nutrisi Ternak Itik. http://yosyhombing.com/2012/04/for mula-kebutuhan-nutri-ternak-

itik.html. (diakses tanggal 20 September 2019).

Siregar, F.R., A. Hintono dan S. Mulyani. 2012. Perubahan sifat fungsional telur ayam ras pasca pasteorisasi. Animal Agriculture 1(1): 521-528.

Steel, R. G. D., dan J. H. Torrie. 1993. Prinsip dan Prosedur Statistika Suatu Pendekatan Biometrik. Alih Bahasa B. Sumantri. PT Gramedia Pustaka Utama. Jakarta.

Tindjabate, R.S., I.K. Suada dan M.J. Rudyanto. 2014. Pengawetan telur ayam ras dengan pencelupan dalam ekstrak air kulit manggis pada suhu ruang. Jurnal Indonesia Medicus Veterinus 3(4): 310-316.

Wedana, I.P.C., I.K.A. Wiyana dan M. Wirapartha. 2017. Pengaruh lama penyimpanan terhadap kualitas fisik telur ras yang diperlihara secara intensif. Journal of Tropical Animal Science 5(1): 1-10.

Wulandari, E., O. Rachmawan, A. Taofik, N. Suwarno dan A. Faisal. 2013. Perendaman telur ayam ras konsumsi terhadap daya awet pada penyimpanan suhu ruang. Jurnal Istek 7(2): 163-274. 